\title{
Practical electrical energy production to solve the shortage in electricity in palestine and pay back period
}

\author{
Ahmed S A Badawi', Nurul Fadzlin Hasbullah ${ }^{2}$, Siti Yusoff ${ }^{3}$, Aisha Hashim ${ }^{4}$, Mohammed Elamassie ${ }^{5}$ \\ ${ }^{1,2,3,4}$ Department of Electrical and Computer Engineering, International Islamic University, Malaysia \\ ${ }^{5}$ Department of Electrical and Electronics Engineering, Özyeğin University, Turkey
}

\section{Article Info \\ Article history: \\ Received Dec 23, 2018 \\ Revised May 7, 2019 \\ Accepted Jun 26, 2019}

\section{Keywords:}

Wind energy

Mean wind speed

Potential energy

\begin{abstract}
In this paper power energy had been estimated based on actual wind speed records in a coastal city in Palestine Ashdod. The main aims of this study to determine the feasibility of wind turbine and to estimate payback period. Therefore, to encourage investment in renewable energy in Palestine. The daily average wind speed data had been analyzed and fitted to the Weibull probability distribution function. The parameters of Weibull had been calculated by author using Graphical method the applied example wind turbine is $5 \mathrm{kw}$ wind turbine generator this is suitable turbine for small scale based on wind speed records on the coastal plain of Palestine. This study calculated the energy that can produce from wind turbine to estimate the revenue of any possible project in wind energy conversion system based on unit area. Energy has been calculated wind energy using two different method based on Weibull data and measured data. The total amount of energy for 2010 is $10749.8 \mathrm{kw} . \mathrm{hr} / \mathrm{m} 2$ based on measured wind speed. Payback period for the project in wind energy turbines is around 3 years which make the generation electricity possible for small scale but not commercial. This study will lead to assess the wind energy production in Palestine to encourage investment in renewable energy sectors.
\end{abstract}

Copyright $@ 2019$ Institute of Advanced Engineering and Science. All rights reserved.

\section{Corresponding Author:}

Nurul Fadzlin Hasbullah,

Department of Electrical and Computer Engineering,

International Islamic University,

Jalan Gombak, 53100 Selangor, Malaysia.

Email: nfadzlinh@iium.edu.my

\section{INTRODUCTION}

The environment of political risk and uncertainty has inhibited investors from making large scale energy or industrial investments. Regardless of all these challenges, Palestine has gone forward to use its natural resources for construction and rehabilitation $[1,2]$. The renewable wind power shows a cheap and feasible solution to spread power generators through large areas worldwide. It turns into one of the most environmental and convenient friendly way of electricity generating. The major capacity of every wind turbines world widely installed by the last of 2017 was 539'291 Megawatt, in reference to preliminary statistics reported by WWEA today [3,4].

With no proven fossil fuel reserves, wind and solar energy are the only indigenous energy resources for the Palestinians. Basically solar energy is used extensively for domestic water heating while wind energy resources have yet to be assessed except some little studies [5]. Therefore, many governments put an ambitious goal to supply a significant portion of their electrical grid from renewable energy such as PV and Wind energy. Figure 1 shows the Palestine map clarifies Ashdod city and coastal plain of Palestine. 


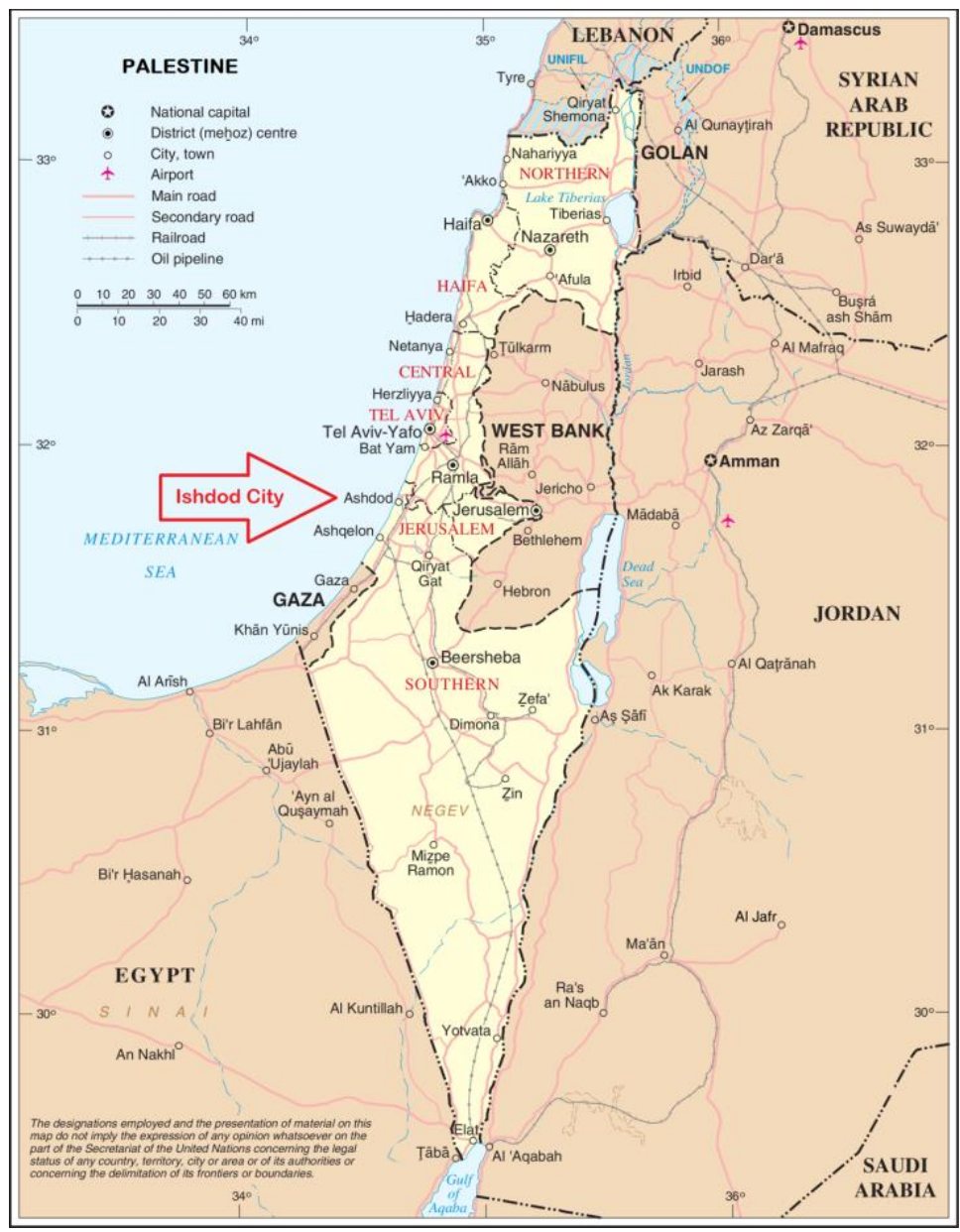

Figure 1. Palestine map clarifies Ashdod city and coastal plain of Palestine [6]

In Palestine, Applications in the renewable energy field are very limited because of small investments in this sector with the remarkable exception of solar water heaters. In the sector of electrical energy, the bulk of the electrical resource to the Palestinian territories drives from Israeli electrical company. This monopoly also affects the cost of electricity, and leads to electricity shortages, with the great threat of a future energy dilemma in the future [2]. Traditional energy resources are lacking while the consumption of non-renewable sources in various fields continues to rise. Therefore, the critical situation in this region, the siege imposed and the growing need for alternative sources of energy have become urgent concerns. Such urgency is highlighted by the continued interruption of electric power and fuel supply.

The available electricity generated by a wind power generation framework in a given wind field depends on the MWS, standard deviation of wind speed and installation location. In this study, we aim to assess the wind energy production in Palestine by analysing wind data using an efficient probability function presented in previous research. Although several studies have been conducted at various Palestine territories, we believe that this study is the first relevant research on the Gaza Strip. We utilise the information recorded from the coastal city of Ashdod in 2010. In this study, wind energy potential has been estimated. Wind energy and power has been calculated based on measured data and Weibull value. The two parameters of Weibull had been estimated by author in the previous study using graphical numerical analysis[7].

\section{WIND ENERGY POTENTIAL}

Wind speed for a given Ashdod sites can be characterized by probability distribution functions (Weibull curve). The Weibull probability distribution function is given by [8].

$F(V)=K \frac{V^{(K-1)}}{C^{K}} e^{-\left(\frac{V}{C}\right)^{K}} \mathrm{k}>0, \quad \mathrm{v}>0, \mathrm{c}>1$ 
Where $f(v)$ the probability of occurrence of speed is, $v$ is the annual MWS, $k$ is a shape factor Weibull parameter (dimensionless), $\mathrm{c}$ is a scale factor with $\mathrm{m} / \mathrm{s}$ units. The parameters of Weibull can be calculated using the annual MWS.

$$
\begin{aligned}
& k=\left(\frac{\sigma}{\bar{v}}\right)^{-1.086}, \quad 1 \leq k \leq 10 \\
& c=\frac{\bar{v}}{\Gamma\left(1-\frac{1}{k}\right)} .
\end{aligned}
$$

Where $\Gamma$ is the complete gamma function. The maximum power that can extracted from the wind given by (3).

$$
\mathrm{P}_{\mathrm{m}}=0.2965 \rho \mathrm{Av}^{3}
$$

Where $A$ is the area swept by the rotor in $\mathrm{m}^{2}, \rho$ is the air density in $\mathrm{kg} / \mathrm{m}^{3}$, and $\mathrm{v}$ is the wind speed in $\mathrm{m} / \mathrm{s}$ as mentioned above.

$$
\begin{aligned}
& \mathrm{E}_{\mathrm{using} \text { weibull }}=\mathrm{P} * \text { Values of Weibull } * 8760=\mathrm{Whr} / \mathrm{m}^{2} \\
& \mathrm{E}_{\text {using data }}=\mathrm{P} * \mathrm{D}=\mathrm{Whr} / \mathrm{m}^{2}
\end{aligned}
$$

Where: yearly mean wind speed $\mathrm{v}$ is depend on the site in $\mathrm{m} / \mathrm{s}$, swept area $\mathrm{A}=1 \mathrm{~m}^{2}$, Weibull shape factor $\mathrm{k}=1.785$ (dimensionless), Weibull scale factor $\mathrm{c}=4.3642 \mathrm{~m} / \mathrm{s}$ density of air $\rho=1.21 \mathrm{~kg} / \mathrm{m}^{3}$, Shape factors and scale factor had been calculating using graphical method. $\mathrm{P}$ is the power available in wind calculated by (4). D is the total time duration of wind speed value in the year.

\subsection{Estimation of wind power density (WPD)}

WPD reflects a target location's wind energy resource in the selection of optimum wind turbines. WPD identifies a location's accessible energy level. It is calculated in two ways: based on measured wind speed data and proper distribution function. This study calculates available power on the capacity [9]. WPD is measured on the basis of the 1) available power specified by the measured mean wind speed (MWS) of the meteorological station and 2) frequency distribution function (two-parameter Weibull method) [10-14]. WPD is an essential indicator to understand the potential of wind resources. It also represents the amount of wind energy at different wind speeds in a particular location. Estimation is performed to predict a) power generation among a grid of wind turbines and (b) future power generation in a given site. Thus payback period and feasibility can be estimated.

In this study $5 \mathrm{~kW}$ wind turbine has been applied to estimate the power and energy per unit area. Therefore, the amount of energy that can produce from the wind generator can lead to calculate the economic feasibility. The amount of power extracted by this wind energy conversion system is represented by the following (1) and (2) [14- 16].

$$
\begin{aligned}
& \mathrm{P}(\text { watt })=0.5 \mathrm{C}_{-} \mathrm{P} \rho \mathrm{A} v^{\wedge} 3 \\
& \lambda=\omega \mathrm{R} / \mathrm{v}
\end{aligned}
$$

Where $C_{-} P$ is the wind power coefficient (function of tip speed ratio, $\lambda$ and pitch angle $\beta$ ), the maximum value of power coefficient is around $53 \%$ based on Betz law (theoretically). However, the best value of the power coefficient is from $35 \%$ to $40 \%$ for most of the wind turbines. $\mathrm{R}$ is the rotor blade radius $(\mathrm{m})$, Where $\rho$ is the air density $\mathrm{kg} / \mathrm{m}^{\wedge} 3, v$ is the wind speed $(\mathrm{m} / \mathrm{s})$ and $\mathrm{A}$ is the area of rotor.

\subsection{Graphical method (GM)}

The GM, also called the LSM [17], is employed using the CDF. In GM, the wind speed record ought to first be categorised into bins. After using the logarithm of equation below twice, the GM equation can be obtained as follows. 


$$
\ln \{-\ln [1-F(v)]\}=k \ln (v)-k \ln (c)
$$

The GM is used by a logarithmic function of the CDF F(v), that is, the CDF F(v) is modulated for the inclusion of a dual logarithmictransformation [18]. Plotting $\ln f_{0}(v)$ as the $x$-axis versus $\ln f_{0}\left\{-\ln \left[f_{0}:(1-\mathrm{F}(\mathrm{v})\}\right.\right.$ as the $\mathrm{y}$-axis shows a straight line in which $\mathrm{k}$ is the slope and the $\mathrm{y}$-intercept is $\operatorname{kn}(\mathrm{c})[7,9,19,20]$. Weibull parameters can be estimated using the GM of every year presented in Figure 2. The first step is to plot the natural logarithm of the observed speed versus $\ln (-\ln (1-\mathrm{F}(v))$. Then, we find the Weibull parameters by linearly fitting the plotted points; here, $\mathrm{k}$ is the slope of the fitted line, and $\mathrm{c}$ is equal to exp $(\mathrm{b} / \mathrm{k})$, where $\mathrm{b}$ is the $\mathrm{y}$-intercept of the fitted line.

Where,

$\ln _{i} f_{0}(v)$ as $x$ axis versus $\ln (-\ln (1-\mathrm{F}(\mathrm{v}))$

$\mathrm{y}=\mathrm{mx}-\mathrm{b}$

Where $\mathrm{m}=\mathrm{k}, \quad \mathrm{b}=\mathrm{k} \ln f_{0}(\mathrm{c})$

$\left.\ln _{\mathrm{L}}^{\mathrm{i}} f_{0}\right)(\mathrm{c})=\mathrm{b} / \mathrm{k}$

$c=e^{\wedge}(b / k)$

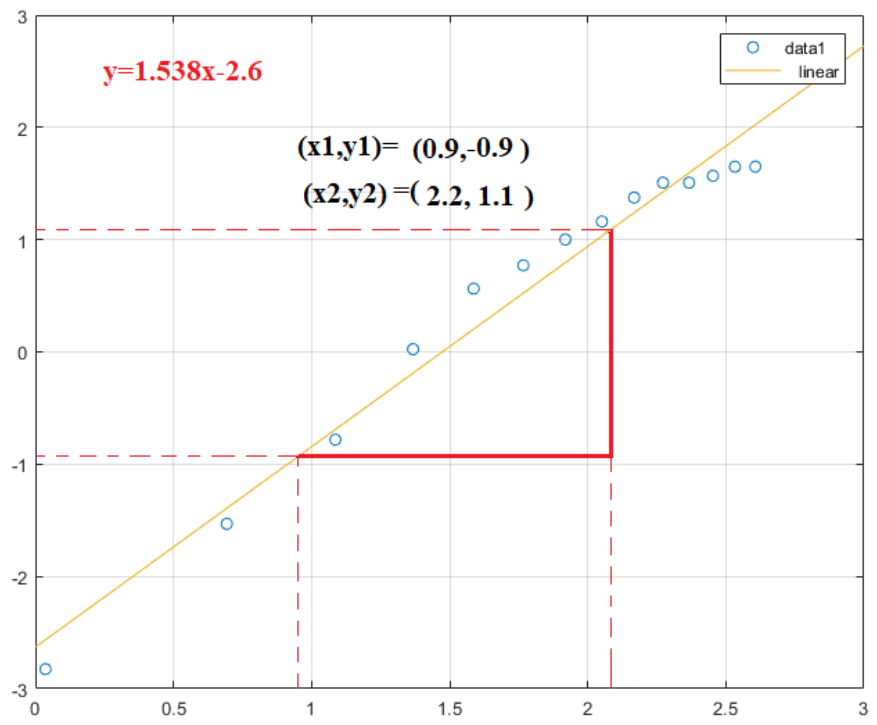

Figure 2. GM estimated results for Ashqelon in 2012

\section{RESULTS AND ANALYSIS}

Wind speed measurement had been measured for Ashdod city during 2010. Wind speed records obtained including the hourly mean wind speed for every single hour from the total ( 8760 a year). The data categorized based on the range for wind speed records. This study calculated the maximum power and power density per unit area from the wind based on the mid range of monthly wind speed.

The energy has been estimated using Weibull value and wind speed measured data. The power calculated using 4 , power density by multiplying the power available with percentage of occurrence, Weibull value using (1), energy using Weibull (5) and finally energy using data by (6). Table 1 lists in detail the mean wind speed in Ashdod site during 2010. Values for percentage of occurrence for each wind speed range, power available in the wind for each range per unit area, power density Weibull values using (1), the total calculated power is 42065.8 watt per unit area. The total estimated energy based on Weibull probability distribution is $18774.7 \mathrm{kWh} / \mathrm{m}^{\wedge} 2$ whereas, the total calculated energy based on the measured is 10749.8 $\mathrm{kWh} / \mathrm{m}^{\wedge} 2$.

Figure 3 illustrates a graphical representation of the distribution of hourly duration for different ranges of wind speed. Figure 4 shows the mean wind speed was fitted well to probability distribution function. It can be clearly noticed that the most of average wind speed values are between 1.5 to $4 \mathrm{~m} / \mathrm{s}$. Figure 5 presents energy estimated based on Weibull value versus energy calculated using measured wind speed data. 
Table 1. Yearly wind speed for 2010, power and energy calculations for Ashdod city [15]

\begin{tabular}{ccccccccc}
\hline $\begin{array}{c}\text { Speed range } \\
(\mathrm{m} / \mathrm{s})\end{array}$ & $\begin{array}{c}\text { Mid } \\
\text { range }\end{array}$ & $\begin{array}{c}\text { Duration } \\
\text { (hours) }\end{array}$ & $\begin{array}{c}\text { Occurrence } \\
\text { percentage } \\
(\%)\end{array}$ & $\begin{array}{c}\text { Power } \\
\left(\mathrm{W} / \mathrm{m}^{\wedge} 2\right)\end{array}$ & $\begin{array}{c}\text { Power density } \\
\left(\mathrm{W} / \mathrm{m}^{\wedge} 2\right)\end{array}$ & $\begin{array}{c}\text { Weibull } \\
\text { values }\end{array}$ & $\begin{array}{c}\text { Energy } \\
\left(\mathrm{kWh} / \mathrm{m}^{\wedge} 2\right) \\
\text { using Weibull }\end{array}$ & $\begin{array}{c}\text { Energy } \\
\left(\mathrm{kWh} / \mathrm{m}^{\wedge} 2\right) \\
\text { using data }\end{array}$ \\
\hline 0 & 0 & 0 & 0 & 0 & 0 & 0 & 0 & 0 \\
$0-1$ & 0.5 & 267 & 3.05 & 0 & 0.0653 & 0.073 & 1.37 & 77.050 \\
$1-2$ & 1.5 & 1760 & 20.09 & 2.14 & 11.59 & 0.152 & 101.55 \\
$2-3$ & 2.5 & 2583 & 29.49 & 57.7 & 78.78 & 0.182 & 426.97 & 690.05 \\
$3-4$ & 3.5 & 1473 & 16.82 & 267.15 & 123.30 & 0.175 & 1125.23 & 1079.78 \\
$4-5$ & 4.5 & 1210 & 13.81 & 733.05 & 215.16 & 0.146 & 1988.56 & 1885.17 \\
$5-6$ & 5.5 & 833 & 9.51 & 1557.99 & 270.52 & 0.108 & 2696.58 & 2369.52 \\
$6-7$ & 6.5 & 359 & 4.1 & 2844.56 & 192.51 & 0.073 & 3001.97 & 1685.63 \\
$7-8$ & 7.5 & 146 & 1.67 & 4695.35 & 120.46 & 0.045 & 2852.87 & 1053.09 \\
$8-9$ & 8.5 & 59 & 0.67 & 7212.92 & 70.35 & 0.026 & 2372.57 & 619.49 \\
$9-10$ & 9.5 & 43 & 0.49 & 10499.88 & 71.83 & 0.014 & 1756.12 & 630.33 \\
$10-11$ & 10.5 & 21 & 0.24 & 14658.8 & 47.50 & 0.007 & 1170.95 \\
$11-12$ & 11.5 & 1 & 0.01 & 19792.26 & 2.60 & 0.003 & 709.71 & 415.64 \\
$12-13$ & 12.5 & 2 & 0.02 & 26002.86 & 6.68 & 0.001 & 393.73 & 26.00 \\
$13-14$ & 13.5 & 3 & 0.03 & 33393.16 & 12.62 & 0.000 & 201.04 \\
Sum & & 8760 & 100 & 42065.77 & 163783.59 & 1 & 18774.72 \\
\hline
\end{tabular}

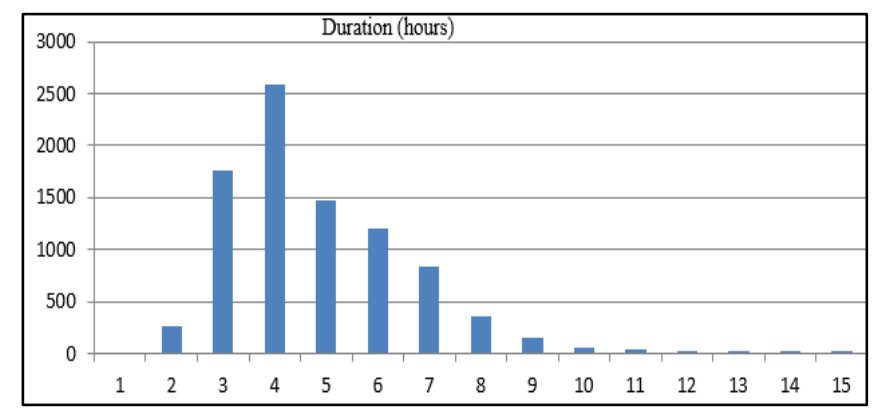

Figure 3. Number of hours per year for each wind speed rang for Ashdod city 2010

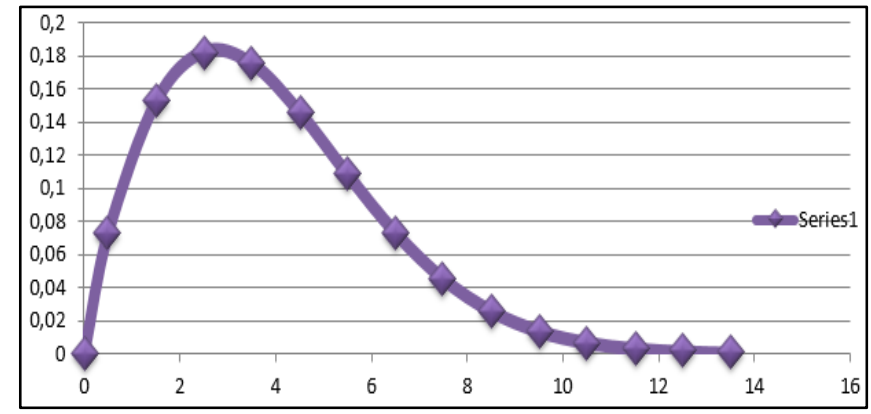

Figure 4. Weibull probability distribution for 2010

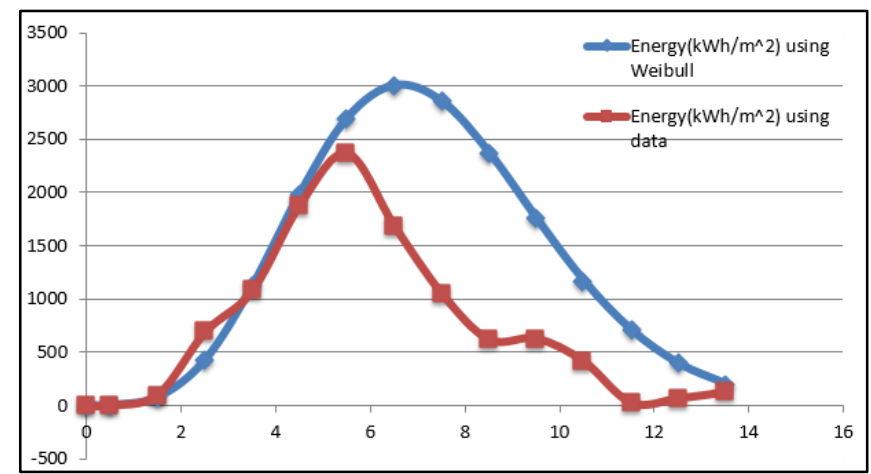

Figure 5. Calculated and estimated energy based on measured data and weibull 


\section{PAYBACK PERIOD}

It can be calculated the payback period of any project by calculating the annual return and the total cost of the installing. The example project is relatively small so the insulation cost is very cheap especially for small scale wind turban. Table 2 shows the annual energy that can produced using $5 \mathrm{~kW}$ wind turbine. The total energy calculated is $10749.8 \mathrm{kw} . \mathrm{hr} / \mathrm{m} 2$. The annual energy that can produce per unit area is 380.39 $\mathrm{kw} . \mathrm{hr} / \mathrm{m} 2$. The annual return for wind turbine $(5 \mathrm{~kW})$ per a year is 1540 \$. Payback period is around 3 years regardless the maintenance and operating fees.

Table 2. Payback period for wind energy conversion system

\begin{tabular}{ll}
\hline Annual energy that can produced using wind turbine & $10749.8 \mathrm{kw} . \mathrm{hr} / \mathrm{m} 2$ \\
Annual energy that can produced per unit area & $380.39 \mathrm{kw} \cdot \mathrm{hr} / \mathrm{m} 2$ \\
$\mathrm{Kw} / \mathrm{hr}$ Bill $(\$)$ & $0.1430 \$$ \\
Annual return turbine $\mathrm{kw} . \mathrm{hr} / \mathrm{m} 2$ a year & $1540 \$$ \\
Payback Period $(\mathrm{yr})(\operatorname{cost} 4500 \$ / \mathrm{m} 2)$ & 2.9 years \\
\hline
\end{tabular}

\section{CONCLUSION}

This study has been calculated the energy that can produced per unit area for Ashdod city in the coastal plain of Palestine. This study represents the Weibull probability distribution. The Weibull value has been calculated based on graphical method. Wind turbine generator $5 \mathrm{~kW}$ was the applied example in this paper due to appropriateness for small scale. Moreover, small wind power generator can start in a light wind, sutaility for the bad environment and can work safely regardless of a furious storm. Energy has been estimated based on Weibull vale and calculated based on measured data. The total energy calculated is $10749.8 \mathrm{kw} \cdot \mathrm{hr} / \mathrm{m}^{2}$. Payback period for small wind turbine generator based on energy value is around 3 years. This study shows the economical feasibility of small scale wind turbine. Therefore, encouraging the investment in this field and state care for this kind of investments.

\section{ACKNOWLEDGMENT}

This work was partially supported by Ministry of Higher Education Malaysia (Kementerian Pendidikan Tinggi) under Fundamental Research Grant Scheme FRGS/1/2018/TK10/UIAM/01/1.

\section{REFERENCES}

[1] A.S.A. Badawi et al., "Weibull Probability Distribution of Wind Speed for Gaza Strip for 10 Years," Applied Mechanics and Materials, vol. 892, pp. 284-291, 2019.

[2] Yaseen B.T., "Renewable Energy Applications in Palestine," in Proceedings of the DISTRES Conference, 2009.

[3] Kitaneh, R., H. Alsamamra, and A. Aljunaidi, "Modeling of wind energy in some areas of Palestine," Energy Conversion and Management, vol. 62, pp. 64-69, 2012.

[4] (WWEA), W.W.E.A., WIND POWER CAPACITY REACHES 539 GW, 52,6 GW ADDED IN 2017. 2018.

[5] Pishgar-Komleh S. H., A. Keyhani, and P. Sefeedpari. "Wind speed and power density analysis based on Weibull and Rayleigh distributions (a case study: Firouzkooh county of Iran)," Renewable and sustainable energy reviews, vol. 42, pp. 313-322, 2015.

[6] (PCBS), P.C.B.o.S., Wind Speed Data, 2018

[7] Badawi A. S. A., "Numerical Analysis for Determining the Weibull Parameters using Seven Techniques in the Mediterranean Coast of Palestine (Under Review)," Renewable energy, Elsevier, Available: https://ees.elsevier.com/rene/default.asp, 2018.

[8] Lun I.Y. and J.C. Lam, "A study of Weibull parameters using long-term wind observations," Renewable energy, vol. 20(2), pp. 145-153, 2000.

[9] Mohammadi K., et al., "Assessing different parameters estimation methods of Weibull distribution to compute wind power density," Energy Conversion and Management, vol. 108, pp. 322-335, 2016.

[10] Parajuli A., "A Statistical Analysis of Wind Speed and Power Density Based on Weibull and Rayleigh Models of Jumla, Nepal," Energy and Power Engineering, vol. 08(07), pp. 271-282, 2016.

[11] Albuhairi M.H., "Assessment and analysis of wind power density in Taiz-republic of Yemen," Ass. Univ. Bull. Environ. Res, vol. 9(2), pp. 13-21, 2006.

[12] Pishgar-Komleh S.H., A. Keyhani, and P. Sefeedpari, "Wind speed and power density analysis based on Weibull and Rayleigh distributions (a case study: Firouzkooh county of Iran)," Renewable and Sustainable Energy Reviews, vol. 42, pp. 313-322, 2015.

[13] Carlin P.W., "Analytical expressions for maximum wind turbine average power in a Rayleigh wind regime," National Renewable Energy Lab., Golden, CO (United States), 1996. 
[14] Badawi A.S.A., "Evaluation of Wind Power for Electrical Energy Generation in the Mediterranean Coast of Palestine for 14 years (Under Review)," International Journal of Electrical and Computer Engineering (IJECE), vol. 9(4), pp. 2212-2219, Aug 2019.

[15] Badawi A.S.A., "An Analytical Study for Establishment of Wind Farms in Palestine to Reach the Optimum Electrical Energy," IUG, 2013.

[16] Badawi, A.S.A., "Energy and Power Estimation for Three Different Locations in Palestine," Indonesian Journal of Electrical Engineering and Computer Science (IJEECS), vol. 14(3), pp. 1049-1056, 2019.

[17] Azad A.K., et al., "Analysis of Wind Energy Prospect for Power Generation by Three Weibull Distribution Methods," Energy Procedia, vol. 75, pp. 722-727, 2015.

[18] Andrade C.F.d., et al., "An efficiency comparison of numerical methods for determining Weibull parameters for wind energy applications: A new approach applied to the northeast region of Brazil," Energy Conversion and Management, vol. 86, pp. 801-808, 2014.

[19] Bilir L., et al., "An investigation on wind energy potential and small scale wind turbine performance at İncek region-Ankara, Turkey," Energy Conversion and Management, vol. 103, pp. 910-923, 2015.

[20] Chang T.P., "Performance comparison of six numerical methods in estimating Weibull parameters for wind energy application," Applied Energy, vol. 88(1), pp. 272-282, 2011.

\section{BIOGRAPHIES OF AUTHORS}

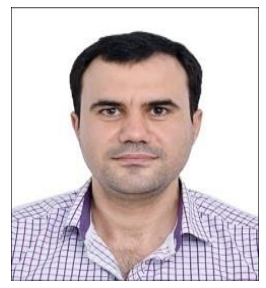

Ahmed S A Badawi, have a $\mathrm{PhD}$ degree in Elrctrical Engineering from International Islamic University Malaysia (IIUM). His study is about maximum power point tracking for small scale wind turbine. Badawi have finished his Master degree in Wind Energy, Control Dept. (2013) Islamic University of Gaza, Gaza, Palestine. Subject: An Analytical Study for Establishment the Wind Farms in Palestine to Reach the Optimum Electrical Energy. Badawi has finished his B.Sc. Electrical Engineering Communication \& Control Dept. (08th June, 2010) from Islamic University Of Gaza, Gaza, Palestine. Awards and Honors: Badawi has been won the Award for Distinguished Graduation Research Projects and Master Dissertations for the year 2011-2012. He has many honors certifications, awards. Within his studying years.

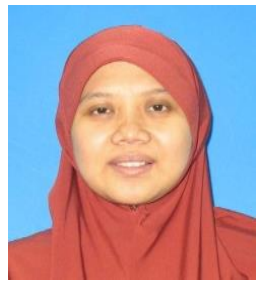

Dr. Nurul Fadzlin Hasbullah, had an Electrical and Electronic Engineering, Cardiff University, 2001 (First Class Honors). PhD in Electronic Engineering, University of Sheffield, Feb. 2010 "Electrical and Optical characterisation of quantum dot laser structures". Dr.Nurul is a member of IEEE, Board of Engineers Malaysia and Institute of Physics Malaysia. Dr.Nurul won $1^{\text {st }}$ silver medal in the Seoul International Invention Fair, 2012 for the general purpose irradiation chamber and the $1^{\text {st }}$ bronze medal in ITEX, 2012 for the general purpose irradiation chamber.

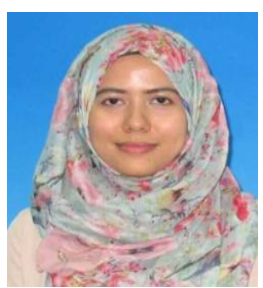

Siti Hajar Binti Yusoff, Assistant Professor at international Islamic University Malaysia. Siti Hajar Yusoff received the M.Eng. Degree in electrical engineering (First Class Honors) and the Ph.D. degree in electrical engineering from University of Nottingham, UK, in 2009 and 2014, respectively. In 2015, she became an Assistant Professor in Department of Electrical and Computer Engineering at International Islamic University Malaysia, Gombak. She is now a lecturer in control of power electronics systems and electrical power system. Her research interests include control of power converters and drives, Matrix, multilevel converters, IoT and renewable energy.

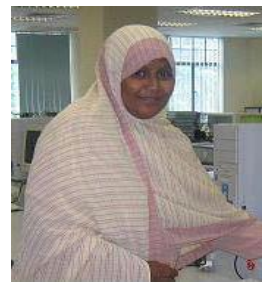

Aisha Hasan Abdullah Hashim, Professor Aisha received her PhD in Computer Engineering (2007), M.Sc. in Computer Science (1996), and B.Sc. in Electronics Engineering (1990). She won the best graduating PhD student Award during the IIUM Convocation ceremony in 2007. She joined IIUM in 1997 and currently working as a Professor at the Department of Electrical and Computer Engineering.

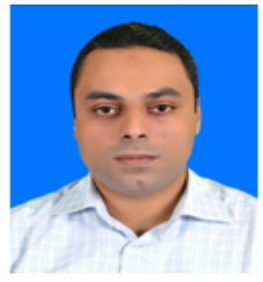

Mohammed Elamassie, a Teaching Assistant at Özyeğin Üniversitesi since Feb. 2015 he got a Bachelor Degree of Science in Electrical Engineering from The Islamic University of Gaza, GazaStrip, Palestine in Jan. 2006. He also received his master degree of Science in Electrical Engineering June 2011 from IUG. He also a Research/Teaching Assistant and Ph.D. candidateSince Feb. 2015 Özyeğin Üniversitesi, Çekmeköy, Istanbul, TURKEY. 